\title{
Photosynthetic activity of Triticum carthlicum Nevski. (=Triticum persicum Vav.) variety samples in the forest-steppe zone of the Northern Trans-Urals
}

\author{
G.V. Tobolova* \\ Federal State Budgetary Educational Institution of Higher Education "Northern Trans-Ural State \\ Agricultural University", Tyumen, Russia
}

\begin{abstract}
The studies of plants' assimilation activity of the Triticum carthlicum Nevski. (=Triticum persicum Vav.) tetraploid species' variety samples have been carried out in the subtaiga zone (Aromashevo) and the northern forest-steppe zone (Tyumen). The number of leaves on plants by zones varied from three to five. Measurements showed that the lamina length varied from $6.4-23.7 \%$ in the northern forest-steppe zone and from 0 to $21.9 \%$ in Aromashevo. The lamina area on the main shoot of the Triticum carthlicum Nevski variety samples in the northern forest-steppe zone amounted to $62.3 \mathrm{~cm}^{2}$, which was $26 \mathrm{~cm}^{2}$ less than in the subtaiga zone. Calculation of net photosynthetic productivity in northern foreststeppe zone showed that Triticum carthlicum Nevski variety samples formed from $10.864 \mathrm{~g}^{*} \mathrm{~m}^{2} /$ day to $20.764 \mathrm{~g}^{*} \mathrm{~m}^{2} /$ day, giving way to durum and soft wheat. In the subtaiga zone, $\mathrm{PP}_{\mathrm{n}}$ of Triticum carthlicum Nevski wheat varied from 9.088 to $13.827 \mathrm{~g}^{*} \mathrm{~m}^{2} /$ day, significantly yielding Bezenchukskaya 139 variety.
\end{abstract}

\section{Introduction}

Over a long period of cultivated plants' selection, their assimilation activity has evolved in a certain way and an increase in the yield of varieties is associated with a change in different elements of photosynthetic productivity depending on the agroecological selection backgrounds, the crops characteristics and directions of selection. According to several scientists, the enlargement of leaves in wheat evolution proceeded in parallel with the enlargement of seeds and ears. Playing a leading role in the ear supply, the flag leaf has received a particularly strong development, and the duration of its active life has increased during the period of grain swelling.

In plant selection, it is very important to increase the photosynthetic productivity of plants. In the process of long-term selection for productivity, forms with larger leaves first appeared. According to A.V. Kulakov [1], the main increase in the yield of modern spring wheat varieties of the Povolzhsky selection center in comparison with its old varieties and the original local variety Poltavka is associated with an increase in leaf surface, and the

\footnotetext{
* Corresponding author: tgv60@mail.ru
} 
selection varieties exceeded Poltavka in this trait both in dry and especially in moist years. At the same time, it turned out that the upper leaves increased much stronger than the lower ones during the selection process. So, on average for 5 years, the area of the first (lower) leaf of Saratovskaya 29 was only $4 \%$ more than the corresponding Poltavka leaf, and the area of the flag leaf - by $44 \%$. As a result of these measurements, the economic suitability coefficient $\left(\mathrm{K}_{\mathrm{ec}}\right)$ of the best varieties increased to $45-46 \%$ versus $38-40 \%$ for Poltavka and old varieties.

The relationship between the top leaf area, its photosynthesis, the productivity of wheat varieties has been noted many times and can be used as a breeding trait for the selection of productive wheat forms $[2,3,4]$. This relationship is weaker in awned wheat and barley due to the higher value of ear photosynthesis in grain swelling $[5,6]$.

The aim of this research was to study the differences in the photosynthesis intensity in the Triticum carthlicum Nevski. (=Triticum persicum Vav.) tetraploid wheat species [7, 8] in comparison with modern varieties of tetraploid, and especially hexaploid wheat.

\section{Materials and methods}

The study of the leaf surface was carried out according to the method of P.P. Litun [9] in the earing phase in 1999-2000 in the zone of the northern forest-steppe (Tyumen) and in the subtaiga zone (Aromashevo village). Measurements were started from the first (bottom) leaf using a special millimeter ruler. The calculation of the leaf surface area was carried out according to the formula:

$$
\mathrm{S}=\mathrm{L} / 4\left(\mathrm{a}_{1}+\mathrm{a}_{2}+1,5 \mathrm{a}_{3}\right)
$$

Where: L - leaf length, cm

$\mathrm{a}_{1}, \mathrm{a}_{2}, \mathrm{a}_{3}$ - leaf width at measurement points, $\mathrm{mm}$

The photosynthesis productivity $(\mathrm{PP})$ and net photosynthesis productivity $\left(\mathrm{PP}_{\mathrm{n}}\right)$ were calculated by the method of A.A. Nichiporovich $[10,11]$ using the formula:

$\mathrm{PP}=1 / 2 \mathrm{~h} * 1 \mathrm{~m}^{2} /$ day.

$\mathrm{PP}_{\mathrm{n}}=\mathrm{Y}_{\text {Biol }} / \mathrm{PP}\left(\mathrm{g} *\right.$ day $\left./ \mathrm{m}^{2}\right)$, where

$\mathrm{h}$ - the leaf surface area on the day of measurement, $\left(\mathrm{m}^{2}\right)$

1 - duration of the growing period (days)

$Y_{\text {biol }}$ - biological yield

For research, 8 Triticum carthlicum Nevski variety samples were taken: K-7885 var. persicum, K-11891 var. rubiginosum, K-13698 var. stramineum, K-14036 var. stramineum + rubiginosum, K-17555 var. rubiginosum, K-17687 var. stramineum, K-19726 var. persicum, K-29288 var. persicum. Tyumenskaya 80 soft wheat variety and Bezenchukskaya 139 durum wheat variety were used as the standard.

\section{Results and discussion}

The number of leaves on Triticum carthlicum Nevski plants varied from 3 to 5 . Most of the plants had four leaves. An analysis plants' sampling in 1999 showed that only variety sample K-7885 had plants with three leaves. They accounted for $1.3 \%$ of all studied plants. The number of plants with five leaves ranged from $21.3 \%$ to $33.8 \%$ (Table 1). The maximum value was noted for Bezenchukskaya 139 durum wheat variety $-81.3 \%$. In the studied varieties, the occurrence frequency of plants with three leaves in Aromashevo conditions was higher than in Tyumen. 
Table 1. The number of plants with three and five leaves per stem, \% (1999-2000).

\begin{tabular}{|c|l|c|c|c|}
\hline It.No. & \multirow{2}{*}{ Variety samples } & \multirow{2}{*}{$\begin{array}{c}\text { Tyumen, } \\
\text { five leaves }\end{array}$} & \multicolumn{2}{|c|}{ Aromashevo } \\
\cline { 4 - 5 } & & 27.5 & 7.5 & three leaves \\
\hline 1 & Tyumenskaya 80 & 30.4 & 0 & five leaves \\
\hline 2 & $\mathrm{~K}-7885$ & 33.8 & 0 & 7.5 \\
\hline 3 & $\mathrm{~K}-11891$ & 23.8 & 2.5 & 5.0 \\
\hline 4 & $\mathrm{~K}-13698$ & 21.3 & 5 & 7.5 \\
\hline 5 & $\mathrm{~K}-14036$ & 21.3 & 2.5 & 12.5 \\
\hline 6 & $\mathrm{~K}-17555$ & 30.0 & 2.5 & 7.5 \\
\hline 7 & $\mathrm{~K}-17687$ & 31.7 & 2.5 & 10.0 \\
\hline 8 & $\mathrm{~K}-19726$ & 26.3 & 0 & 15.0 \\
\hline 9 & $\mathrm{~K}-29288$ & 81.3 & 0 & 10.0 \\
\hline 10 & Bezenchukskaya 139 & & & \\
\hline
\end{tabular}

Studies have shown that the lamina length in Triticum carthlicum Nevski plants in the northern forest-steppe zone (experimental field of the TSAA) varied in the first leaf from $17.9 \%$ to $23.7 \%$ (Figure 1). The variation coefficient of the second leaf length was 9.8-17.5\%. The variation coefficient of the third leaf was higher $(\mathrm{CV}=6.4 \%-18.9 \%)$. The length of the fourth leaf varied from 20 to $26 \mathrm{~cm}(\mathrm{CV}=10.5 \%-14.7 \%)$. The fifth leaf ranged from $14 \mathrm{~cm}(\mathrm{~K}-7885)$ to $19.1 \mathrm{~cm}(\mathrm{~K}-17555)$ in length (Table 2).

Table 2. The lamina length in the Triticum carthlicum Nevski variety samples,

Tyumen 1999-2000.

\begin{tabular}{|l|c|c|c|c|c|c|c|c|c|c|}
\hline \multirow{2}{*}{$\begin{array}{c}\text { Cultivar, } \\
\text { variety } \\
\text { sample }\end{array}$} & \multicolumn{2}{|c|}{ I leaf } & \multicolumn{2}{c|}{ II leaf } & \multicolumn{2}{c|}{ III leaf } & \multicolumn{2}{c|}{ IV leaf } & \multicolumn{2}{c|}{ V leaf } \\
\cline { 2 - 12 } & $\mathrm{CV} \%$ & $\mathrm{~L} \mathrm{~cm}$ & $\mathrm{CV} \%$ & $\mathrm{~L} \mathrm{~cm}$ & $\mathrm{CV} \%$ & $\mathrm{~L} \mathrm{~cm}$ & $\mathrm{CV} \%$ & $\mathrm{~L} \mathrm{~cm}$ & $\begin{array}{c}\text { CV } \\
\%\end{array}$ \\
\hline Tyum80 & $13.9 \pm 0.42$ & 27.2 & $19.4 \pm 0.37$ & 16.9 & $20.9 \pm 0.5$ & 21.4 & $26.1 \pm 0.49$ & 11.8 & $11.4 \pm 0.73$ & 29.9 \\
\hline K-7885 & $14.3 \pm 0.38$ & 23.7 & $19.6 \pm 0.39$ & 17.5 & $22.5 \pm 0.48$ & 18.9 & $26.1 \pm 0.49$ & 11.8 & $14.0 \pm 0.61$ & 21.4 \\
\hline K-11891 & $13.5 \pm 0.29$ & 19.7 & $19.7 \pm 0.26$ & 11.6 & $23.3 \pm 0.32$ & 12.3 & $20.7 \pm 0.31$ & 13.3 & $16.8 \pm 0.52$ & 16.3 \\
\hline K-13698 & $14.7 \pm 0.26$ & 15.9 & $20.7 \pm 0.25$ & 10.9 & $24.4 \pm 0.2$ & 7.3 & $21.7 \pm 0.27$ & 11.3 & $18.6 \pm 0.64$ & 14.9 \\
\hline K-14036 & $15.1 \pm 0.27$ & 15.9 & $20.6 \pm 0.22$ & 9.8 & $24.1 \pm 0.17$ & 6.4 & $21.1 \pm 0.25$ & 10.5 & $16.7 \pm 0.81$ & 19.9 \\
\hline K-17555 & $16.9 \pm 0.23$ & 12.2 & $20.5 \pm 0.24$ & 10.3 & $23.9 \pm 0.24$ & 8.9 & $21.3 \pm 0.26$ & 10.8 & $19.1 \pm 0.64$ & 13.9 \\
\hline K-17687 & $15.3 \pm 0.32$ & 18.9 & $19.6 \pm 0.24$ & 11 & $23.3 \pm 0.23$ & 8.7 & $21.3 \pm 0.26$ & 10.8 & $18.3 \pm 0.43$ & 11.5 \\
\hline K-19726 & $14.3 \pm 0.29$ & 17.9 & $18.5 \pm 0.32$ & 15.3 & $22.6 \pm 0.21$ & 8.2 & $20.2 \pm 0.33$ & 14.7 & $16.8 \pm 0.38$ & 11.3 \\
\hline K-29288 & $14.1 \pm 0.32$ & 20.3 & $17.9 \pm 0.33$ & 16.5 & $21.9 \pm 0.28$ & 14.2 & $19.9 \pm 0.38$ & 16.9 & $17.1 \pm 0.51$ & 13.7 \\
\hline $\begin{array}{l}\text { Bezench } \\
\text { ukskaya } \\
139\end{array}$ & $16.0 \pm 0.29$ & 16.4 & $21.0 \pm 0.32$ & 13.8 & $24.2 \pm 0.26$ & 9.5 & $21.6 \pm 0.4$ & 16.7 & $16.5 \pm 0.33$ & 16.2 \\
\hline LSD 05 & 1.42 & & 1.35 & & 1.39 & & 1.57 & & 2.37 & \\
\hline
\end{tabular}

In Aromashevo conditions (subtaiga zone), the lamina length in Triticum carthlicum Nevski in terms of plant layers did not reliably exceed the leaf length of the Tyumenskaya 80 variety (Table 3). The smallest percentage of length variation was observed in Triticum carthlicum Nevski on the last (fifth, flag) leaf (0-7.4\%).

Table 3. The lamina length in the Triticum carthlicum Nevski variety samples, Aromashevo 1999-2000.

\begin{tabular}{|l|c|c|c|c|c|c|c|c|c|c|}
\hline $\begin{array}{c}\text { Cultivar, variety } \\
\text { sample }\end{array}$ & \multicolumn{2}{|c|}{ I leaf } & \multicolumn{2}{c|}{ II leaf } & \multicolumn{2}{c|}{ III leaf } & \multicolumn{2}{c|}{ IV leaf } & \multicolumn{2}{c|}{ V leaf } \\
\cline { 2 - 13 } & L cm & CV\% & L cm & CV\% & L cm & CV\% & L cm & CV\% & L cm & $\begin{array}{c}\text { CV } \\
\%\end{array}$ \\
\hline Tyum 80 & $15.1 \pm 0.7$ & 27.9 & $23.2 \pm 0.6$ & 14.9 & $25.4 \pm 0.6$ & 15.1 & $25.7 \pm 0.5$ & 11.9 & $27.3 \pm 0.5$ & 5.5 \\
\hline K-7885 & $16.9 \pm 0.3$ & 13 & $22.1 \pm 0.5$ & 14.3 & $26.7 \pm 0.4$ & 10.1 & $26.4 \pm 0.6$ & 10.9 & $27.0 \pm 0.9$ & 6.4 \\
\hline K-11891 & $16.8 \pm 0.4$ & 14.2 & $21.8 \pm 0.5$ & 14 & $26.5 \pm 0.4$ & 10 & $26.3 \pm 0.5$ & 10.9 & $28.5 \pm 0.5$ & 2.5 \\
\hline K-13698 & $16.5 \pm 0.5$ & 19.1 & $21.8 \pm 0.5$ & 14.7 & $26.1 \pm 0.4$ & 10.1 & $25.9 \pm 0.5$ & 12.6 & $27 \pm 0.9$ & 7.4 \\
\hline K-14036 & $16.4 \pm 0.5$ & 20.1 & $22.6 \pm 0.6$ & 16.3 & $26.7 \pm 0.5$ & 11.2 & $26 \pm 0.6$ & 12.8 & $26.3 \pm 0.9$ & 5.8 \\
\hline K-17555 & $15.9 \pm 0.5$ & 19.8 & $21.5 \pm 0.6$ & 16.5 & $26.2 \pm 0.4$ & 10.7 & $25.8 \pm 0.5$ & 11.4 & $27.4 \pm 0.6$ & 4.9 \\
\hline K-17687 & $17.1 \pm 0.5$ & 18.9 & $22.5 \pm 0.5$ & 14.5 & $26.2 \pm 0.5$ & 11.1 & $25.8 \pm 0.6$ & 13.7 & $28.0 \pm 0.1$ & 0 \\
\hline
\end{tabular}




\begin{tabular}{|l|c|c|c|c|c|c|c|c|c|c|}
\hline K-19726 & $16.6 \pm 0.5$ & 20 & $22.3 \pm 0.5$ & 13.8 & $25.9 \pm 0.6$ & 14.2 & $26.3 \pm 0.5$ & 11.8 & $28.3 \pm 0.3$ & 1.8 \\
\hline K-29288 & $14.9 \pm 0.5$ & 21.9 & $21.8 \pm 0.6$ & 17.6 & $25.7 \pm 0.4$ & 13.6 & $25.7 \pm 0.4$ & 10.1 & $26.7 \pm 0.4$ & 3.9 \\
\hline $\begin{array}{l}\text { Bezenchukskaya } \\
139\end{array}$ & $15.9 \pm 0.6$ & 21.9 & $21.8 \pm 0.6$ & 16.2 & $25.8 \pm 0.7$ & 17.8 & $26.1 \pm 0.5$ & 11.8 & $28.4 \pm 0.4$ & 3.1 \\
\hline LSD $_{05}$ & 2.29 & & 2.42 & & 2.35 & & 3.49 & & 3.33 & \\
\hline
\end{tabular}

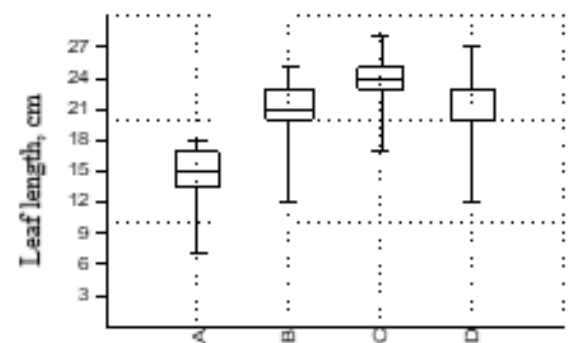

a

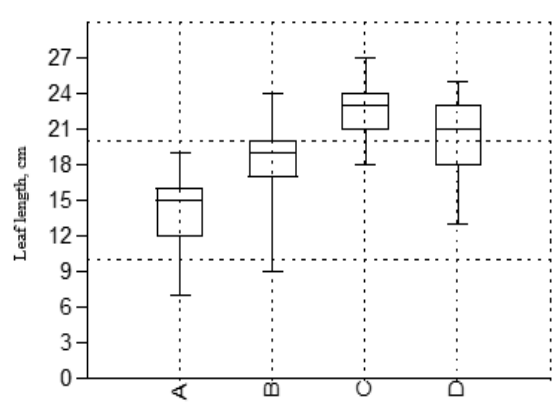

$\mathrm{b}$

Fig. 1. Diagram of the range of deviation in leaf length in the Triticum carthlicum Nevski variety samples: a - K-13698; b - K-19726. Note: * - A-first leaf, B-second leaf, C-third leaf, D-fourth leaf.

The length of the flag leaf in plants at two points of the study differed by varieties. In Aromashevo, the flag leaf of Triticum carthlicum Nevski plants was $7.3 \mathrm{~cm}$ longer than in Tyumen (Table 4). No significant differences were found between the variety samples in Aromashevo, the flag leaf length ranged from 25.9 to $26.5 \mathrm{~cm}$. In Tyumen, the flag leaf of the soft wheat variety was shorter than that of the Triticum carthlicum Nevski variety samples and Bezenchukskaya 139 and had $\mathrm{L}=14 \pm 0.39 \mathrm{~cm}$.

Table 4. The length of the flag leaf in the Triticum carthlicum

Nevski variety samples, 1999-2000.

\begin{tabular}{|c|c|c|c|c|}
\hline \multirow{2}{*}{$\begin{array}{c}\text { Variety sample } \\
\text { cultivar }\end{array}$} & \multicolumn{2}{|c|}{ Tyumen } & \multicolumn{2}{c|}{ Aromashevo } \\
\cline { 2 - 5 } & $\mathrm{L}, \mathrm{cm}$ & $\mathrm{CV}, \%$ & $\mathrm{~L}, \mathrm{~cm}$ & $\mathrm{CV}, \%$ \\
\hline Tyumenskaya 80 & $14 \pm 0.39$ & 25.2 & $26.2 \pm 0.46$ & 11.5 \\
\hline $\mathrm{K}-7885$ & $14.9 \pm 0.39$ & 22.9 & $26.3 \pm 0.44$ & 10.6 \\
\hline $\mathrm{K}-11891$ & $18.9 \pm 0.35^{*}$ & 16.5 & $26.3 \pm 0.45$ & 10.9 \\
\hline $\mathrm{K}-13698$ & $20.6 \pm 0.29^{*}$ & 12.9 & $26 \pm 0.51$ & 12.5 \\
\hline $\mathrm{K}-14036$ & $19.8 \pm 0.31^{*}$ & 14.2 & $26.2 \pm 0.52$ & 12.6 \\
\hline $\mathrm{K}-17555$ & $20.4 \pm 0.25^{*}$ & 10.8 & $25.9 \pm 0.45$ & 11 \\
\hline $\mathrm{K}-17687$ & $19.4 \pm 0.23^{*}$ & 10.4 & $25.9 \pm 0.56$ & 13.7 \\
\hline $\mathrm{K}-19726$ & $18.4 \pm 0.28^{*}$ & 13.5 & $26.4 \pm 0.48$ & 11.6 \\
\hline K-29288 & $17.9 \pm 0.46^{*}$ & 23.1 & $25.9 \pm 0.41$ & 10.1 \\
\hline $\begin{array}{c}\text { Bezenchukskaya } \\
139\end{array}$ & $17.1 \pm 0.32^{*}$ & 16.8 & $26.5 \pm 0.49$ & 11.9 \\
\hline LSD 05 & 1.50 & & 1.83 & \\
\hline
\end{tabular}

The lamina area on the main shoot of the Triticum carthlicum Nevski variety samples in the northern forest-steppe zone ranged from $54.6 \mathrm{~cm}^{2}(\mathrm{~K}-7885)$ to $68.8 \mathrm{~cm}^{2}(\mathrm{~K}-17555)$ and significantly exceeded the soft wheat variety Tyumenskaya 80 (Table 5). However, not a single variety sample has surpassed the durum wheat variety Bezenchukskaya 139 (79.5 $\mathrm{cm}^{2}$ ) on this indicator. In the subtaiga zone, the leaf area of the Triticum carthlicum Nevski variety samples was almost twice as large as in Tyumen. For the standard, it amounted to $88.5 \mathrm{~cm}^{2}$ and differed in a lower coefficient of variation $(\mathrm{CV}=6.3 \%)$ in comparison with the Triticum carthlicum Nevski variety samples. 
Table 5. Leaf surface area of the Triticum carthlicum Nevski variety samples, 1999-2000.

\begin{tabular}{|c|c|c|c|c|}
\hline \multirow{2}{*}{$\begin{array}{c}\text { Variety sample, } \\
\text { cultivar }\end{array}$} & \multicolumn{2}{|c|}{ Tyumen } & \multicolumn{2}{c|}{ Aromashevo } \\
\cline { 2 - 5 } & $\mathrm{S}, \mathrm{cm}^{2}$ & $\mathrm{CV}, \%$ & $\mathrm{~S}, \mathrm{~cm}^{2}$ & $\mathrm{CV}, \%$ \\
\hline Tyumenskaya 80 & 48.6 & 14.5 & 88.5 & 6.3 \\
\hline $\mathrm{K}-7885$ & 54.6 & 9.2 & 89.3 & 12.5 \\
\hline $\mathrm{K}-11891$ & 59.4 & 5.7 & 88.4 & 12.5 \\
\hline $\mathrm{K}-13698$ & 64.6 & 5.7 & 88.1 & 15.3 \\
\hline $\mathrm{K}-14036$ & 62.2 & 5.1 & 88.7 & 11.4 \\
\hline $\mathrm{K}-17555$ & 68.8 & 8.2 & 86.8 & 14.4 \\
\hline $\mathrm{K}-17687$ & 67.8 & 6.9 & 89.4 & 10.8 \\
\hline $\mathrm{K}-19726$ & 61.9 & 7.9 & 89.3 & 10.2 \\
\hline K-29288 & 59.1 & 12.6 & 86.4 & 16.3 \\
\hline Bezenchukskaya 139 & 79.7 & 9.2 & 86.6 & 10.5 \\
\hline LSD 05 & 5.5 & & 15.6 & \\
\hline
\end{tabular}

The leading role in the assimilants' supply to the ear belongs to the upper (flag) leaf, the size of which is strongly influenced by the growing conditions (\%). Comparative analysis of Persian wheat variety samples indicates that the flag leaf area in the northern foreststeppe zone was significantly higher than the standard and amounted to $12.9-15.1 \mathrm{~cm}^{2}$ (Table 6). The exception was the variety sample K-7885, which had the smallest flag leaf surface $(\mathrm{CV}=19.9 \%)$. The surface of the flag leaf in the subtaiga zone was twice as large as in Tyumen, but no significant differences were found between the variety samples. The variation in the flag leaf area in the Persian wheat variety samples in Aromashevo ranged from 11.8 to $17.6 \%$. While for the standard it amounted to $\mathrm{CV}=8.3 \%$.

Table 6. The leaf surface area of the flag leaf, 1999-2000.

\begin{tabular}{|c|c|c|c|c|}
\hline \multirow{2}{*}{ Variety samples } & \multicolumn{2}{|c|}{ Tyumen } & \multicolumn{2}{c|}{ Aromashevo } \\
\cline { 2 - 5 } & leaf S, $\mathrm{cm}^{2}$ & $\mathrm{CV}, \%$ & leaf $\mathrm{S}, \mathrm{cm}^{2}$ & $\mathrm{CV}, \%$ \\
\hline Tyumenskaya 80 & 7.2 & 26.6 & 27.8 & 8.3 \\
\hline $\mathrm{K}-7885$ & 8.4 & 19.9 & 27.9 & 14.3 \\
\hline $\mathrm{K}-11891$ & 12.9 & 10.8 & 28.0 & 14.2 \\
\hline $\mathrm{K}-13698$ & 15.1 & 16.6 & 27.5 & 17.6 \\
\hline $\mathrm{K}-14036$ & 14.2 & 13.5 & 27.9 & 15.3 \\
\hline $\mathrm{K}-17555$ & 15.8 & 8.8 & 27.1 & 12.3 \\
\hline $\mathrm{K}-17687$ & 15.0 & 10.2 & 28.2 & 14.3 \\
\hline $\mathrm{K}-19726$ & 13.6 & 10.4 & 28.1 & 12.3 \\
\hline $\mathrm{K}-29288$ & 13.9 & 16.3 & 27.2 & 11.8 \\
\hline $\mathrm{K}-49901$ & 11.6 & 17.9 & 28.5 & 14.4 \\
\hline LSD 05 & 4.0 & & 2.52 & \\
\hline
\end{tabular}

Photosynthetic potential is an integral indicator of plant photosynthesis and an important yield-related trait. According to V.A. Kumakov (1980, 1985), the variation in yield over the years is associated with the variability of the leaf surface and photosynthetic potentials. The highest PP was formed in the northern forest-steppe zone in the K-17555 variety sample - $33.2 \mathrm{~m}^{2}$ per day. While Tyumenskaya 80 soft wheat had low PP (22.6 $\mathrm{m}^{2} /$ day) and Bezenchukskaya 139 durum wheat had the highest $-39.05 \mathrm{~m}^{2} /$ day (Table 7). Under subtaiga conditions, no significant differences in photosynthetic potential were found between the Triticum carthlicum Nevski variety samples.

The net productivity of photosynthesis shows the specific productivity of the leaf apparatus. In the zone of the northern forest-steppe, it was the highest in the K-7885 variety sample $\left(28.328 \mathrm{~g}^{*} \mathrm{~m}^{2} /\right.$ day $)$ but did not exceed this indicator of Tyumenskaya 80 soft wheat $-32.958 \mathrm{~g}^{*} \mathrm{~m}^{2}$ per day. In the subtaiga zone, $\mathrm{PP}_{\mathrm{n}}$ of all variety samples was lower than in northern forest zone; a sharp decrease was observed in soft wheat $-19.203 \mathrm{~g}^{*} \mathrm{~m}^{2} /$ day, while 
the net photosynthetic efficiency of Triticum carthlicum Nevski variety samples was reduced by only $1,398-6.968 \mathrm{~g}^{*} \mathrm{~m}^{2} /$ day.

Table 7. Photosynthetic potential of Persian wheat plants' leaves, 1999-2000.

\begin{tabular}{|c|c|c|c|c|c|}
\hline \multirow{2}{*}{ It.No. } & \multirow{2}{*}{ Variety sample } & \multicolumn{2}{|c|}{ Tyumen } & \multicolumn{2}{c|}{ Aromashevo } \\
\cline { 3 - 6 } & & $\begin{array}{c}\mathrm{PP}, \\
\mathrm{m}^{2} / \text { day }\end{array}$ & $\mathrm{PP}_{\mathrm{n}}, \mathrm{g}^{*} \mathrm{~m}^{2} /$ day & $\mathrm{PP}, \mathrm{m}^{2} /$ day & $\mathrm{PP}_{\mathrm{n}}, \mathrm{g}^{*} \mathrm{~m}^{2} / \mathrm{day}$ \\
\hline 1 & Tyumenskaya 80 & 22.605 & 32.958 & 42.020 & 13.755 \\
\hline 2 & $\mathrm{~K}-7885$ & 26.476 & 28.328 & 43.745 & 12.847 \\
\hline 3 & $\mathrm{~K}-11871$ & 28.493 & 18.601 & 42.893 & 12.986 \\
\hline 4 & $\mathrm{~K}-13698$ & 32.922 & 15.035 & 43.624 & 11.690 \\
\hline 5 & $\mathrm{~K}-14036$ & 30.474 & 14.635 & 44.372 & 10.772 \\
\hline 6 & $\mathrm{~K}-17555$ & 33.211 & 10.990 & 42.949 & 9.593 \\
\hline 7 & $\mathrm{~K}-17687$ & 32.218 & 10.864 & 43.352 & 9.088 \\
\hline 8 & $\mathrm{~K}-19726$ & 30.671 & 15.813 & 44.200 & 10.520 \\
\hline 9 & $\mathrm{~K}-29288$ & 28.680 & 20.746 & 42.337 & 13.817 \\
\hline 10 & Bezenchukskaya 139 & 39.045 & 22.538 & 42.001 & 15.833 \\
\hline
\end{tabular}

\section{Conclusion}

The assimilation surface of leaves in the Triticum carthlicum Nevski variety samples in the northern forest-steppe zone varied from $54.6 \mathrm{~cm}^{2}$ to $68.8 \mathrm{~cm}^{2}$ significantly exceeding soft wheat but yielding in this indicator to the Bezenchukskaya 139 durum wheat variety $(79.5$ $\mathrm{cm}^{2}$ ). In the subtaiga zone, the leaf area of the Triticum carthlicum Nevski variety samples was almost twice as large as in the northern forest-steppe zone, no significant differences between cultivars were found.

The greatest photosynthetic potential was formed in the zone of the northern foreststeppe in the variety sample K-17555 - $33.2 \mathrm{~m}^{2}$ per day. Under subtaiga conditions, no significant differences in photosynthetic potential were found between the Triticum carthlicum Nevski variety samples.

The net photosynthesis productivity showed that the Triticum carthlicum Nevski variety samples did not exceed the standard varieties Tyumenskaya 80 and Bezenchukskaya 139.

\section{References}

1. A.V. Kulakov, Practical course on plant physiology, 136 (1961)

2. O.O. Stasik, D.A. Kiriziy, G.A. Pryadkina, Photosynthesis and productivity of agricultural plants. Plant Physiology and Genetics, 48 (3), 232-251 (2016)

3. N.V. Perfiliev, O.A. Vyushina, Bulletin of KRasGAU, 2 (125), 27-31 (2017)

4. E.V. Ionova, V.L. Gaze, V.A. Likhovidova, Grain Economy of Russia, 1, 23-27 (2020) (In Russ.) https://doi.org/10.31367/2079-8725-2020-67-1-23-27

5. V.A. Kumakov, Agricultural Biology, 3 (3), 362 (1968)

6. V.A. Kumakov, Selection to increase the photosynthetic productivity of plants. Plant physiology. Theoretical foundations of increasing plant productivity, 3, 107 (1981)

7. G.V. Tobolova, Bulletin of the Kursk Agricultural Academy, 9, 132-134 (2018)

8. G.V. Tobolova, In the book: Plant Genetics. Genomics. Bioinformatics and Biotechnology. The $3^{\text {rd }}$ International Conference, Abstract book, 57 (2015) 
9. P.P. Litun, Selection and Seed Production, 2, 24-28 (1976)

10. A.A. Nichiporovich, Photosynthesis and Theory of High Yields, 92 (1956)

11. A.A. Nichiporovich, Theoretical Foundations of Photosynthetic Productivity, 511-527 (1972) 